\title{
Preliminary study of solute carrier family 23 member 3 (SLC23A3) gene as candidate marker for fatty acid traits in Kampung-Broiler crossbred chickens
}

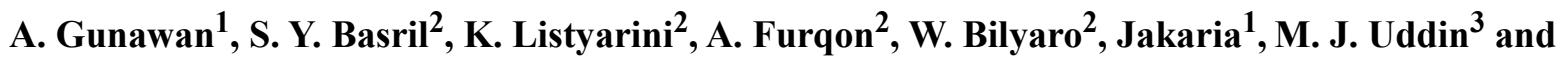 \\ C. Sumantri ${ }^{1, *}$ \\ ${ }^{1}$ Department of Animal Production and Technology, Faculty of Animal Science, \\ Bogor Agricultural University, Jl. Agatis, Dramaga Campus, Bogor 16680 - Indonesia \\ ${ }^{2}$ Graduate School of Bogor Agricultural University, \\ Bogor Agricultural University, Jl. Agatis, Dramaga Campus, Bogor 16680 Bogor - Indonesia \\ ${ }^{3}$ School of Veterinary Science, The University of Queensland, Gatton Campus, \\ Gatton Qld 4343 - Australia \\ *Corresponding E-mail: csumantri12@gmail.com
}

Received March 20, 2018; Accepted June 05, 2018

\begin{abstract}
ABSTRAK
SLC23A3 merupakan gen yang memiliki peranan penting yang mengontrol komposisi asam lemak pada daging. Tujuan dari penelitian ini adalah untuk mengidentifikasi asosiasi dan mengukur ekspresi mRNA gen SLC23A3 sebagai kandidat gen untuk komposisi asam lemak. Sebanyak 62 ekor ayam persilangan F2 Kampung $\times$ Broiler digunakan dalam penelitian ini. Komposisi asam lemak diukur pada ayam umur 12 minggu dari sampel otot paha ayam sebagai parameter penelitian. Metode analisis yang digunakan adalah PCR-RFLP dan qRT-PCR masing-masing untuk menentukan keterkaitan antara gen SLC23A3 dengan komposisi asam lemak dan mengukur tingkat ekspresi gen SLC23A3 pada fenotipe ayam dengan perbedaan komposisi asam lemak. Hasil penelitian menunjukkan SNP gen SLC23A3 pada daerah exon c.22385690 $\mathrm{A}>\mathrm{C}$ berasosiasi secara nyata $(\mathrm{P}<0.05)$ dengan komposisi asam lemak diantaranya asam stearat (C18:0), asam elaidat (C18:1n9t) dan asam linoleat (C18:2n6c). Ekspresi gen SLC23A3 dideteksi terekspresi tinggi di hati baik pada sampel dengan kandungan asam lemak tinggi (HFA) maupun kandungan asam lemak rendah (LFA). Namun, ekspresi gen SLC23A3 tidak ditemukan adanya perbedaan pada HFA dan LFA. Hasil ini memberikan pemahaman lebih baik dan komprehensif mengenai peranan penting gen SLC23A3 terhadap komposisi asam lemak pada hati dan lebih menerangkan secara jelas kandidat seleksi berbasis genomik pada ayam terkait komposisi asam lemak.

Kata kunci: keragaman, ekspresi mRNA, SLC23A3, seleksi, asam lemak tak jenuh
\end{abstract}

\section{ABSTRACT}

SLC23A3 is one of the key genes which control the properties of the of fatty acids content in the meat. The aim of this study was to identify the association of SNP and mRNA expression of SLC23A3 as a candidate marker for fatty acid traits (FAs). Sixty two F2 Kampung $\times$ Broilers crossbred chickens population were used in this study. FA composition was measured at 12 weeks of age from thigh meat of crossbred chicken. The PCR-RFLP and qRT-PCR were used for association study and expression analysis of SLC23A3 gene with divergent fatty acid composition. A SNP in coding region c. 22385690 $\mathrm{A}>\mathrm{C}$ of the SLC23A3 gene was associated $(\mathrm{P}<0.05)$ with fatty acid composition including stearic acid (C18:0), elaidic acid (C18:1n9t), and linoleic acid (C18:2n6c). The SLC23A3 was detected in liver from 
high fatty acids (HFA) and low fatty acid (LFA) composition. However, gene expression of SLC23A3 were not differentially expressed between HFA and LFA. These results will explain better understanding of the key important role of the SLC23A3 in fatty acid traits within the liver and will propose SLC23A3 as a potential genomic selection for selection of chickens with fatty acid composition.

Keywords: polymorphism, mRNA expression, SLC22A3, selection, unsaturated fatty acid

\section{INTRODUCTION}

SLC23A3 (solute carrier family 23 (monocarboxylate transporter), member 3 ), is an orphan transport and its play important role in the uptake and reabsorption of different substrates other that ascorbic acid (Bürzle et al., 2013). The SLC23A3 and other SLC family plays an important role in fatty acid compositions (SLC2A12, SLC5A1, SLC16A7), amino acid transporters (SLC1A1, SLC1A2, SLC1A3, SLC1A6 and SLC1A7) (Lemos et al., 2009; Corominas et al., 2013; Berton et al., 2016). Using RNA deep sequencing analysis of the chicken liver tissues our group has recently identified that the SLC23A3 gene expression was higher in chickens with higher unsaturated fatty acids than the lower unsaturated fatty acids groups (Gunawan et al., 20017). Furthermore, SLC23A3 could be proposed as candidate marker gene for fatty acid traits since its chromosomal position on chromosom 7 is integrated with some Quantitative Trait Loci (QTL) area for fatty acid traits (QTL Database, 2017).

Fatty acid traits influences an important factor in meat quality, its affect into the nutritional value and also to the flavour quality of meat (Yu et al., 2013). Fatty acids, especially unsaturated (UFA) that consist monounsaturated (MUFAs) and some polyunsaturated (PUFAs) are recognised as health beneficial. The capability to geneticaly choose for animal that consider to the consumers preference in term of high unsaturated fatty acids (UFA) that can be predicted would benefit the chicken industry. Fatty acids heritabilities from previous studies were moderate to high, underlining the advantage of a genetic approach to increase UFA concentration over nutritional regulation (Bastin et al., 2011; Nafikov et al., 2013).

Unsaturated fatty acids (UFA) are considered has many advantages for human health. Several research investigation revealed hypocholesterolemic influences to unsaturated fatty acids; MUFA and PUFA (Demaison and Moreau, 2002). The commonly health benefit has been associated with n-3 PUFA which are important for growth and development (Simopoulos, 2008). Long chain n-3 PUFA (docosahexaenoic acid and eicosapentaenoic acid) reported important for immune traits such as antiinflammatory and immunosuppressive component in human (Williams, 2000; Garg et al., 2006). In contrast, a high proportion of saturated fatty acids (SFA) (C12:0; $\mathrm{C} 14: 0$ and $\mathrm{C} 16: 0)$ is associated with cardiovascular disease and mortality percentage in human (Rioux and Legrand, 2007). The negative influence of SFA is correlated through increase in blood cholesterol concentrations in case of lowdensity lipoprotein cholesterol (Williams, 2000). In chickens, the liver is the source of fatty acid synthesis arround $95 \%$ and it is commonly predicted almost all fat concentration in adipose tissue (Zhang et al., 2017). The fatty acid composition is a quantitative trait that is difficult to measure and very expensive to analysis, unlike the growth and linier body measurement, which are easier to record. It is crucial role to investigate the parameter traits such as candidate gene approach for breeding selection that are correlated with the fatty acid composition. Several candidate gene such as Adipose Fatty Acid Binding Protein (AFABP), Fatty Acid Transport Protein 1 (FATP1), Fatty Acid Synthase (FASN), dan Stearoyl Co-A Desaturase (SCD) have been proposed for fatty acid (FA) composition in different chickens population. AFABP and FATP1 gene were associated with fatness (Wang et al., 2006) and meat traits (Wang et al., 2010) in Chinese meat-type quality chicken populations, respectively. Maharani et al. (2013) revealed that FASN and SCD gene association with fatty acid traits in broilers. Furthermore, Furqon et al. (2017) reported that gen expression and single nucleotide polymorphisms (SNP) detection of SCD gene were significantly different on polyunsaturatd fatty acids in Indonesian kampung-broiler crossbred chickens. Investigation of novel SNP within genes cooperating with fatty acid compositions and their genomic analysis throught association analysis and mRNA expression is represent functional analysis generally applied tools to identify key important genes. Therefore, the aim of this study 
was to identify SLC23A3 in detail through SNP detection and gene expression to prove its candidacy for fatty acid traits in Kampung-Broiler chickens.

\section{MATERIALS AND METHODS}

\section{Animals and Phenotypes}

DNA and phenotypic data of chickens were collected from our resource population of F2 Kampung and Broiler $(\mathrm{KB}, \mathrm{n}=62)$ crossbred chickens. The $\mathrm{F}_{2}$ generation of chickens were kept at field laboratory station "Block A", Department Animal Production and Technology, Faculty of Animal Sciences, Bogor Agricultural University. The F2 generation of chicken were kept under the same feeding treatment until twelve weeks old with the average of slaughter weight $1.6 \mathrm{~kg}$. The carcass and meat quality data were collected consider to guidelines of the Indonesian performance test. Tissues from breast muscle were isolated for DNA extraction and total lipids for fatty acid component analysis. Total lipids for each sample were extracted from breast muscle (BM) refered to Folch et al. (1957) procedure for fatty acid analysis. Fatty acid traits measurements consisted saturated fatty acids (SFA), monounsaturated fatty acids (MUFA), polyunsaturated fatty acids (PUFA), and total fatty acids (TFA) from sixty two F2 Kampung and Broiler crossbred chickens were described in Gunawan et al (2018). The general description of fatty acid compositions of $F_{2}$ Kampung- Broiler crossbred chickens are shown in Table 1.

\section{DNA Isolation, PCR Amplification and SNP Detection}

Several SNP have been described recently by our group by comparing breast muscle (BM) with divergent unsaturated fatty acids (Gunawan et al., 2017). Among them, a SNP of SLC23A3 c. $22385690 \mathrm{~A}>\mathrm{C}$ gene was selected for association study. For this purpose, Kampung $\times$ Broilers $(n=62)$ as Indonesian crossbred chickens population were genotyped. For PCR RFLP, genomic DNA was extracted from the breast muscle $(\mathrm{BM})$ tissue of the Kampung $\times$ Broiler crossbred chickens refered to phenol-chloroform method (Gunawan et al., 2011). By comparing from online database NCBI and genomic region of SLC23A3 revealed the possible targets for PCR amplification. The master mix of PCR consisted a $20 \mu \mathrm{L}$ volume containing $2 \mu \mathrm{L}$ of sample DNA, buffer (with $1.5 \mathrm{mM} \mathrm{MgCl}_{2}$ ), $0.25 \mathrm{mM}$ of dNTP, 5 $\mathrm{pM}$ of each primer and $0.1 \mathrm{U}$ of Taq DNA polymerase (GeneCraft). The genotyping method was conducted using PCR-RFLP. The PCR product was visualized using $1.5 \%$ agarose gel (Fischer Scientific Ltd) and digested by using the restriction enzymes of NdeI. The details of PCRRFLP pattern, accession numbers of gene and DNA primer used in this study are presented in Table 2.

\section{Data Analysis}

Gene frequency consist alleles and genotypes were calculate using Chi square test. The association of SLC23A3 gene with fatty acid composition was performed by General Linear Model (GLM) using SAS. 9.2 software The model of GLM was as follows:

Y $i j k l=\mu+$ genotype $i+\operatorname{sex} j+$ eijk

Where, Yijkl is the fatty acid traits $\mu$ is overall mean, genotype $i$ is the fixed effect of $\mathrm{i}$-th genotype (i=AA, $\mathrm{AC}$, and $\mathrm{CC}$ ) and sex $j$ is the fixed effect of $j$-th sex $(j=$ cock $/$ hen $)$ and eijk is the residual error. Least square mean values for the loci genotypes were compared by t-test and pvalues were adjusted by the Tukey-Kramer correction (Kayan et al., 2011; Cinar et al., 2012).

\section{Gene Expression of SLC23A3 in Divergent Fatty Acid Compositions}

The sample tissues from 6 chicken liver with different fatty acid composition were isolated for mRNA study base on genotype results. The 6 chickens were divided into two groups: high fatty acid composition (HFA) which represent by AC genotype and low fatty acid composition (LFA) which represent AA genotype on the basis of unsaturated fatty acids [elaidic acid (C18:1n9t) and linoleic acid (C18:2n6c)] and saturated fatty acid [stearic acid (C18:0)]. For the animals LFA chickens these parameters were vice-versa. The differential gene expression between high and low fatty acids was preformed using proc GLM test in SAS.

For the qRT-PCR analysis, cDNA was synthesized using SuperScript II reverse transcriptase (Invitrogen). Gene specific primers for SLC23A3 for the qRT-PCR were designed by using the Primer3 software (Rozen and Skaletsky, 2000) as presented in Table 2. In each run, the 96well microtiter plate contained each cDNA sample and no-template control. The qRT-PCR was performed with the following program according 
Table 1. The Mean Values and Standard Deviation of Fatty Acid Compositions of $F_{2}$ Kampung and Broiler crossbred Chickens

\begin{tabular}{lcc}
\hline \multicolumn{1}{c}{ Traits } & Mean & SD \\
\hline Fat content & $\ldots \ldots \ldots \ldots \ldots \ldots \ldots \ldots \ldots \ldots \ldots \ldots \ldots \ldots \ldots \ldots \ldots \ldots \ldots \ldots \ldots$ \\
Lauric acid (C12:0) & 4.61 & 1.56 \\
Myristic acid (C14:0) & 0.04 & 0.01 \\
Myristoleic Acid (C14:1) & 0.54 & 0.05 \\
Pentadecanoic Acid (C15:0) & 0.08 & 0.03 \\
Palmitic Acid (C16:0) & 0.09 & 0.04 \\
Palmitoleic Acid (C16:1) & 19.65 & 1.62 \\
Heptadecanoic Acid (C17:0) & 2.46 & 0.75 \\
Stearic Acid (C18:0) & 0.17 & 0.03 \\
Elaidic Acid (C18:1n9t) & 5.26 & 0.73 \\
Oleic Acid (C18:1n9c) & 0.15 & 0.03 \\
Linoleic Acid (C18:2n6c) & 31.31 & 1.99 \\
Arachidic Acid (C20:0) & 20.64 & 1.78 \\
$\gamma$-Linoleic Acid (C18:3n6) & 0.16 & 0.04 \\
Cis 11, 14-Eicosedienoic Acid (C20:2) & 0.1 & 0.02 \\
Behenic Acid (C22:0) & 0.16 & 0.03 \\
Arachidonic Acid (C20:4n6) & 0.06 & 0.03 \\
Docosahexaaonic (C22:6n3) & 0.7 & 0.27 \\
Fatty Acid Total & 0.07 & 0.03 \\
Saturated Fatty Acid & 81.68 & 4.29 \\
Monounsaturated Fatty Acid & 20.72 & 1.64 \\
Polyunsaturated Fatty Acid & 33.39 & 2.52 \\
\hline SD:Standard & 21.66 & 1.85 \\
\hline
\end{tabular}

SD: Standard deviation

to Gunawan et al. (2013a) and Gunawan et al. (2013b). The housekeeping genes (GAPDH) was used for reference of the target gene of SLC23A3 (Table 2). The delta $\mathrm{Ct}(\Delta \mathrm{Ct})$ method were used for calculating the difference between target gene and the reference gene: $\left(\Delta \mathrm{Ct}=\mathrm{Ct}_{\text {target }^{-}}\right.$ $\left.\mathrm{Ct}_{\text {housekeeping genes }}\right)$ as described previously (Silver et al., 2003). The result of graph were quantified as fold change calculated from delta Ct-values. The differences phenotype between high and low FA of SLC23A3 gene expressions were determined using $t$ tests. The values of significant $(\mathrm{P}<0.05)$ were considered to indicate statistically significant differences.

\section{RESULTS}

\section{Gene Polymorphism}

A synonymous SNP was genotyped in SLC23A3 (c.22385690A >C). The SNPs of SLC23A3 were segregated in Kampung-Broiler crossbred chickens population. The SNP c. $22385690 \mathrm{~A}>\mathrm{C}$ of SLC23A3 were polymorphism: $364 \mathrm{bp}$ for the AA genotype and 364,222 , and 142 bp for the AC genotype and 222, 142 bp for CC genotype. In this study, two genotype AA and AC were found for SNP at c. $22385690 \mathrm{~A}>\mathrm{C}$ in resource population (Figure 1). However, we had no found $\mathrm{CC}$ genotype in this study. Homozygote AA was more frequent, 
and heterozygote $\mathrm{AC}$ was rare in population. In this study, the genotype frequency of polymorphism in SLC23A3 (c.22385690A>C) was detected in Hardy Weinberg Equlibrium (HWE) $(\mathrm{P}<0.05)$. The gene frequency including genotype and allele frequency of SLC23A3 are presented in Table 3.

\section{Association of Polymorphisms with Fatty Acids Compositions}

Association analysis of SLC23A3 (c.22385690A $>$ C) fatty acid traits showed significant $(\mathrm{P}<0.05)$ association with unsaturated fatty acids including stearic acid (C18), elaidic acid (C18:1n9t), and linoleic acid (C18:2n6c) as presented in Table 4. Animals with heterozygous AC genotype were associated with high unsaturated fatty acids linoleic acid (C18:2n6c), eicosadienoic acid (C20:2) and higher stearic acid (C18:0). However, the result of association should be confirmed and validated in larger population and breed differences.

\section{mRNA Expression of SLC23A3 in Divergent Fatty Acids Composition}

Gene expression of SLC23A3 showed the

Table 2. GenBank Accession Numbers and Primer Sequences

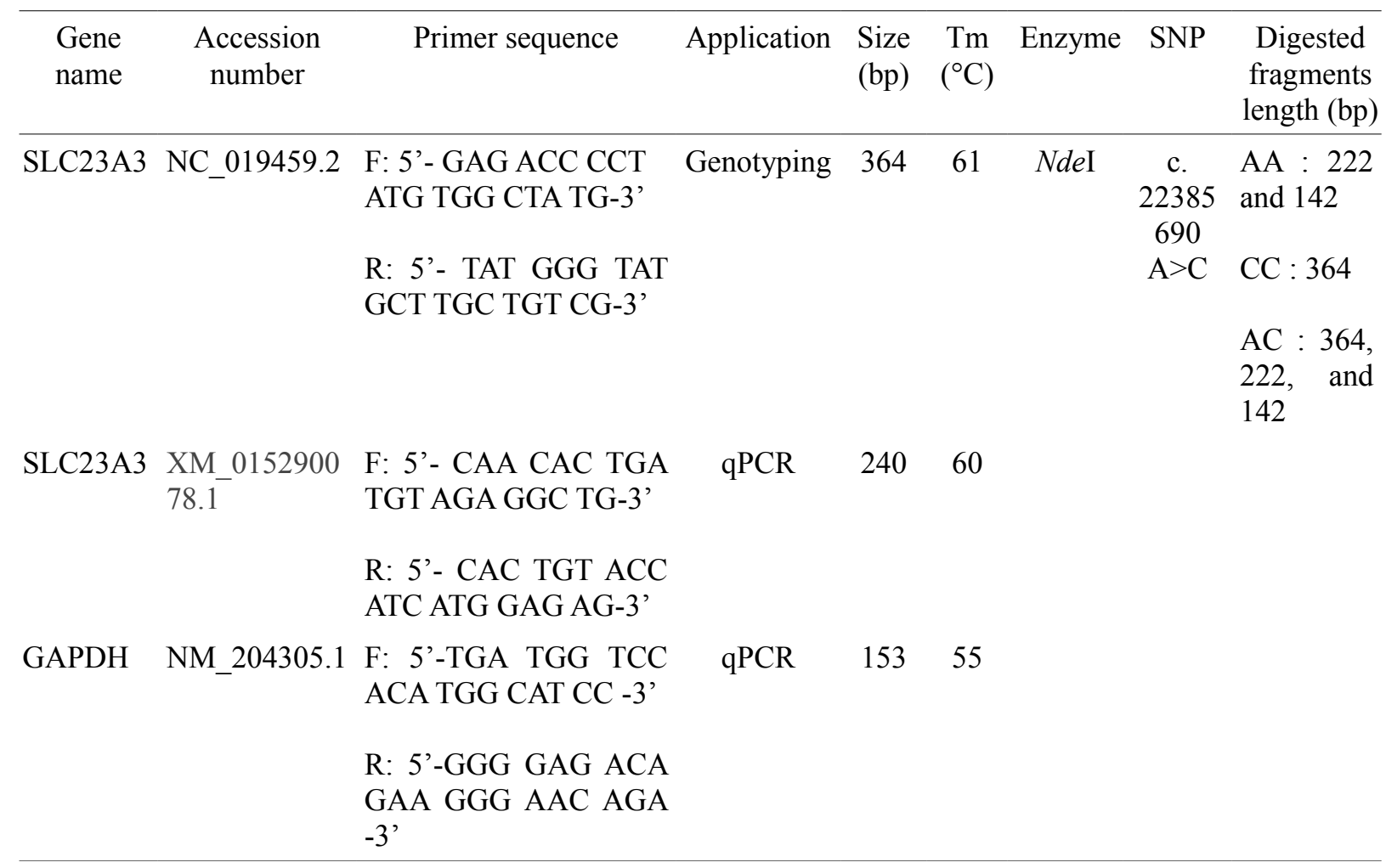

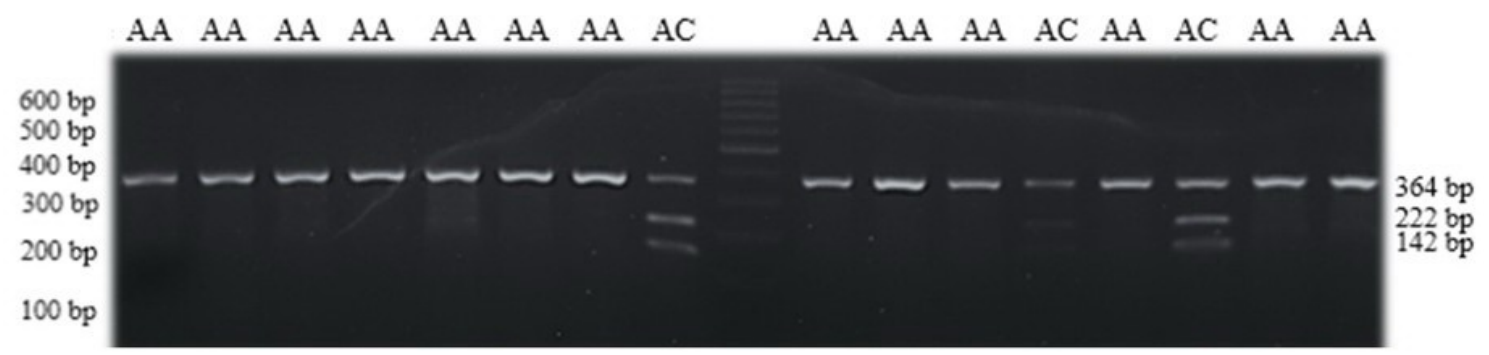

Figure 1. PCR-RFLP Product of SLC23A3 Gene 
Table 3. The Number of Animals per Genotype and Allele Frequency of Each SNP

\begin{tabular}{|c|c|c|c|c|c|c|c|}
\hline \multirow{2}{*}{ Sample } & \multirow{2}{*}{$\mathrm{N}$} & \multicolumn{3}{|c|}{ Genotype Frequency } & \multicolumn{2}{|c|}{ Allele Frequency } & \multirow{2}{*}{$x^{2}$} \\
\hline & & $\mathrm{AA}$ & $\mathrm{AC}$ & $\mathrm{CC}$ & A & $\mathrm{C}$ & \\
\hline $\begin{array}{l}\text { Indonesian crossbred chicken } \\
\text { (F2 Kampung } \times \text { Broiler) }\end{array}$ & 62 & $0.81(50)$ & $0.19(12)$ & - & 0.60 & 0.40 & 0.012 \\
\hline
\end{tabular}

higher expression transcript in chickens with different fatty acid (FA) composition. The SLC23A3 was detected in liver from HFA (AC genotype) and LFA (AA genotype). However, mRNA expression was not between HFA and LFA $(\mathrm{P}>0.05)$. Higher expression of SLC23A3 was detected similar between chickens with HFA and animals with LFA composition in the liver (Figure 2).

\section{DISCUSSION}

Considering the important role of the SLC23A3 gene, we select to identify an association study the novel of SNP SLC2323A3 with fatty acid traits based on our RNA sequencing result, physiological and structural function through chromosomal position that cooporated several QTL for meat and fatty acids in chickens. The exonic SNP in SLC23A3 (c.22385690A $>$ C) was found as significantly associated with fatty acid composition including stearic acid (C18:0), elaidic acid (C18:1n9t) and linoleic acid (C18:2n6c) as presented in Table 4. Stearic acid (C18:0) is a key role factor in the metabolize of unsaturated fatty acids, which have characteristic of unstable and less harmful to human health (Feitosa et al., 2016). Linoleic acid
(C18:2) is included as PUFA group that have a good relationship to the flavour of meat and is reported to be associated with human health (Yu et al., 2013; Cameron et al., 2002). Lu et al. (2008) reported better meat flavour intensity in native animal because of linoleic fatty acid composition. Additionally, it has been speculated that the meat of native chicken is positive correlation to human health because these unsaturated fatty acid including elaidic acid (C18:1n9t) and linoleic acid (C18:2n6c) are essential for the human body and health (Tapiero et al., 2002). However, such studies are lacking in chickens making it difficult to compare our results. SLC23A3 is an including transporter group gene that has important role as transporter factor for reabsorption processes and homeostasis in the body. This study inagreement with previous study that reported SLC family were correlated with fatty acid (Maekawa et al., 2015). Previous study reported that other SLC familly SLC27A3 (also know as FATP3) play important role for supplying and balancing fatty acid in the brain during the growth and developmental phase. (Maekawa et al., 2015). In fact, findings so far have suggested that there is genetic different in the SLC23A3 gene affecting fatty acid composition of muscles and adipose tissue.

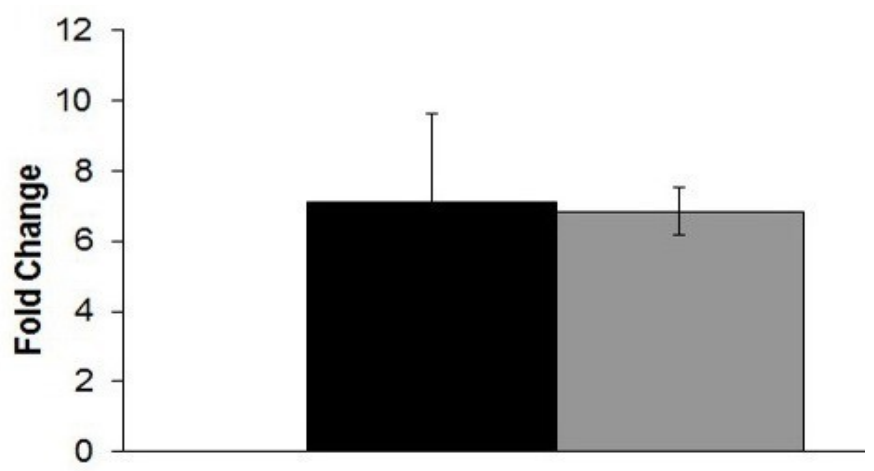

Figure 2. mRNA Expression of SLC23A3 Gene in the Liver from Divergent Phenotype between High (ロ) and Low ( $\square$ ) Fatty Acid Composition 
Table 4. Genotype and Association Analysis of SLC23A3 Gene

\begin{tabular}{|c|c|c|c|}
\hline \multirow[b]{2}{*}{ Trait } & \multicolumn{3}{|c|}{ Genotype } \\
\hline & $\begin{array}{c}\text { AA } \\
(n=50)\end{array}$ & $\begin{array}{c}\mathrm{AC} \\
(\mathrm{n}=12)\end{array}$ & $\begin{array}{c}\mathrm{CC} \\
(\mathrm{n}=0)\end{array}$ \\
\hline Fat content & $4.69 \pm 1.59$ & $4.27 \pm 1.45$ & 0.00 \\
\hline Lauric Acid (C12:0) & $0.04 \pm 0.01$ & $0.04 \pm 0.01$ & 0.00 \\
\hline Myristic acid (C14:0) & $0.54 \pm 0.05$ & $0.56 \pm 0.05$ & 0.00 \\
\hline Myristoleic Acid (C14:1) & $0.08 \pm 0.03$ & $0.08 \pm 0.02$ & 0.00 \\
\hline Pentadecanoic Acid (C15:0) & $0.09 \pm 0.05$ & $0.09 \pm 0.01$ & 0.00 \\
\hline Palmitic Acid (C16:0) & $19.59 \pm 1.60$ & $19.90 \pm 1.76$ & 0.00 \\
\hline Palmitoleic Acid (C16:1) & $2.44 \pm 0.76$ & $2.53 \pm 0.74$ & 0.00 \\
\hline Heptadecanoic Acid (C17:0) & $0.17 \pm 0.03$ & $0.17 \pm 0.03$ & 0.00 \\
\hline Stearic Acid (C18:0) & $5.27 \pm 0.68^{\mathrm{a}}$ & $5.22 \pm 0.97^{\mathrm{b}}$ & 0.00 \\
\hline Elaidic Acid (C18:1n9t) & $0.14 \pm 0.03^{\mathrm{c}}$ & $0.16 \pm 0.03^{\mathrm{d}}$ & 0.00 \\
\hline Oleic Acid (C18:1n9c) & $31.17 \pm 2.01$ & $31.91 \pm 1.84$ & 0.00 \\
\hline Linoleic Acid (C18:2n6c) & $20.44 \pm 1.76^{\mathrm{c}}$ & $21.47 \pm 1.67^{\mathrm{d}}$ & 0.00 \\
\hline Arachidic Acid (C20:0) & $0.16 \pm 0.04$ & $0.17 \pm 0.03$ & 0.00 \\
\hline$\gamma$-Linoleic Acid, C18:3n6 & $0.10 \pm 0.02$ & $0.10 \pm 0.02$ & 0.00 \\
\hline Cis 11, 14-Eicosedienoic Acid (C20:2) & $0.16 \pm 0.03$ & $0.17 \pm 0.02$ & 0.00 \\
\hline Behenic Acid (C22:0) & $0.06 \pm 0.03$ & $0.06 \pm 0.02$ & 0.00 \\
\hline Arachidonic Acid (C20:4n6) & $0.70 \pm 0.28$ & $0.71 \pm 0.23$ & 0.00 \\
\hline Docosahexaaonic (C22:6n3) & $0.06 \pm 0.03$ & $0.07 \pm 0.03$ & 0.00 \\
\hline Fatty Acid Total & $81.26 \pm 4.11$ & $83.43 \pm 5.23$ & 0.00 \\
\hline SFA & $20.66 \pm 1.61$ & $20.98 \pm 1.84$ & 0.00 \\
\hline MUFA & $33.83 \pm 2.65$ & $34.67 \pm 1.87$ & 0.00 \\
\hline PUFA & $21.46 \pm 1.85$ & $22.51 \pm 1.70$ & 0.00 \\
\hline
\end{tabular}

Mean \pm SD are units of percentage fatty acid composition

${ }^{a b}$ Mean value with different superscript letters in the same row differ significantly at $\mathrm{P}<0.05$

The mRNA expression of SLC23A3 was detected in liver from HFA (AC genotype) and LFA (AA genotype). However, mRNA expression was not differentially expressed between HFA and LFA ( $\mathrm{P}>0.05)$. Higher expression of SLC23A3 was detected similar between chickens with HFA and animals with LFA composition in the liver show its an important role related to fatty acid traits. Maekawa et al. (2015) reported SLC23A3 is higher expression in the testis, ovary, lung, and brain. The solute carrier family (SLC) are transporter proteins that regulate homeostasis though iron ion body and skeletal muscle for meat quality traits (Robach et al., 2007). Gunawan et al. (2013) reported four variants of SLC group genes including SLC22A7, SLC25A1 and SLC25A25 related to liver metabolism for unpleasant odour in pig (boar taint) and were identified higher expression and SLC9A4 was found to be lower expression in the high skatole 
group. Grindfleck et al. (2011) previously reported that two variants of SLC family (SLC22A13 and SLC22A14) genes were revealed to be candidate genes for unpleasant odour and flavour in boars. However, to best our knowledge no study has been conducted so far to show the involvement of SLC23A3 related to fatty acids traits in chicken. Higher transcript abundance of SLC23A3 in high and PUFA composition might cause of shift in fatty acid metabolism via upregulating the SLC23A3 gene. SLC23A3 gene may control other fatty acid degradation by PUFA synthesis to determine the fatty acid traits of the muscles, but this speculation will need further validation. It could be suggested as the evidence that the Indonesian crossbred Kampung $\times$ Broilers crossbred chickens show good flavour intensity and are beneficial for human health because of higher unsaturated fatty acids linoleic acid (C18:2n6c), eicosadienoic acid (C20:2) and higher stearic acid (C18:0). Therefore, the selection of chickens having linoleic acid (C18:2) and eicosadienoic acid (C20:2) and stearic acid (C18:0) may provide benefits for human health and the association and expression in chicken SLC23A3 gene could be used as genomic selection for breeding objective in the chicken farm and industry.

\section{CONCLUSION}

Associations and expression of SLC23A3 gene polymorphisms with fatty acid composition have been described for the first time in Indonesian crossbred chicken, providing fact that SLC23A3 might be an important as potential marker for fatty acid traits. However, this study has to be validated in other chickens populations and different breed in order to determine its potential in selective breeding. Finally, the SLC23A3 might play an important factor in fatty acids traits validated through association study and gene expression analysis in liver tisues.

\section{ACKNOWLEDGMENTS}

This work was financially supported by Directorate of Research and Community Service Directorate General of Strengthening Research and Development Ministry of Research, Technology, and Higher Education Fiscal Year 2016 through PSU Project with the Number: 079/SP2H/LT/DRPM/II/2016.

\section{REFERENCES}

Bastin, C., N. Gengler and H. Soyeurt. 2011. Phenotypic and genetic variability of production traits and milk fatty acid contents across days in milk for Walloon Holstein first-parity cows. J. Dairy Sci. 94(8):4152-4163

Berton, M.P., L.F. Fonseca, D.F. Gimenez, B.L. Utembergue, A.S. Cesar, L.L. Coutinho, M.V.A. De Lemos, C. Aboujaoude, A.S. Pereira, M.D.O. Rafael and N.B. Stafuzza. 2016. Gene expression profile of intramuscular muscle in Nellore cattle with extreme values of fatty acid. BMC Genomics. 17:972.

Bürzle, M., Y. Suzuki, D. Ackermann, H. Miyazaki, N. Maeda. B. Clémençon, R. Burrier and M.A. Hediger. 2013. The sodium-dependent ascorbic acid transporter family SLC23. Mol. Aspect Med. 34(23):436-454

Cameron, N.D., M. Enser, and G.R. Nute. 2000. Genotype with nutrition interaction on fatty acid composition of intramuscular fat and the relationship with flavour of pig meat. Meat. Sci. 55(2):187-195.

Cinar, M.U., A. Kayan, M.J. Uddin, E. Jonas and D. Tesfaye. 2012. Association and expression quantitative trait loci (eQTL) analysis of porcine AMBP, GC and PPP1R3B genes with meat quality traits. Mol Biol Rep. 39(4):4809-4821.

Corominas, J., Y. Ramayo-Caldas, A. PuigOliveras, J. Estelle, A. Castello, E. Alves, R.N. Pena, M. Ballester and J.M. Folch. 2013. Analysis of porcine adipose tissue transcriptome reveals differences in de novo fatty acid synthesis in pigs with divergent muscle fatty acid composition. BMC Genomics. 14:843

Demaison, L. and D. Moreau. 2002. Dietary n-3 polyunsaturated fatty acids and coronary heart disease-related mortality: a possible mechanism of action. Cell. Mol. Life Sci. 59(3):463-477.

Feitosa FLB., B.F. Olivieri, C. Aboujaoude, A.S.C. Pereira, M.V.A de Lemos, H.L.J. Chiaia, M.P. Berton, E. Peripolli, A.M. Ferrinho, L.F. Mueller, M.R. Mazalli, L.G. de Albuquerque, H.N de Oliveira, H. Tonhati, R. Espigolan, R. L. Tonussi, R.M.O. Silva, D.G.M Gordo, A.F.G Magalhães, I. Aguilar and F. Baldi. 2016. 
Genetic correlation estimates between beef fatty acid profile with meat and carcass traits in Nellore cattle finished in feedlot. J. Appl. Genet. 58(1):123-132

Folch, J., M. Lee and G. Sloane-Stanley. 1957. A simple method for the isolation and purification of total lipids from animal tissues. J. Biol. Chem. 226(1):497-509.

Furqon, A., A. Gunawan, N. Ulupi, T. Suryati and C. Sumantri. 2017. Expression and association of SCD gene polymorphisms and fatty acid compositions in chicken cross. Med. Pet. 40(3):151-157

Garg, M.L., L.G. Wood, H. Singh and P.J. Moughan. 2006. Means of delivering recommended levels of long chain n-3 polyunsaturated fatty acids in human diets. J. Food Sci. 71(5): R66-R71.

Grindflek, E., S. Lien S, H. Hamland, M.H. Hansen, M. Kent M, M. Van Son and T.H. Meuwissen. 2011. Large scale genome-wide association and LDLA mapping study identifies QTLs for boar taint and related sex steroids. BMC Genomics. 12:362.

Gunawan, A., K. Kaewmala, M.J. Uddin, M.U. Cinar, D. Tesfaye, C. Phatsara, E. Tholen, C. Looft and K. Schellander. 2011. Association study and expression analysis of porcine ESR1 as a candidate gene for boar fertility and sperm quality. Anim. Reprod. Sci. 128: 11-21.

Gunawan, A., S. Sahadevan, C. Neuhoff, C. Große-Brinkhaus, A. Gad, L. Frieden, D. Tesfaye, E. Tholen, C. Looft, M.J. Uddin and K Schellander. 2013a. RNA deep sequencing reveals novel candidate genes and polymorphisms in boar testis and liver tissues with divergent androstenone levels. PloS one. 8(5):e63259.

Gunawan, A., S. Sahadavan, M.U. Cinar, C.C. Neuhoff, C. Große-Brinkhaus, L. Frieden, D. Tesfaye, E. Tholen, C. Looft, D.S Wondim, M. Hölker, K. Schellander and M.J. Uddin. 2013b. Identification of the novel candidate genes and variants in boar liver tissues with divergent skatole levels using RNA deep sequencing. PLoS ONE 8 (8):e 72298

Gunawan, A., E.S. Nurajizah, K. Listyarini, A. Furqon, W. Bilyaro, C. Sumantri, Jakaria, S.H. Akter and M.J. Uddin. 2018. Association study and expression analysis of stearoyl Co-A desaturase as a candidate gene for fatty acid composition in
Indonesian crossbred chickens. Int. J. Poult. Sci. 17(7):348-355.

Jeong J., X. Shi, X. Zhang, S. Kim and C. Shen. 2011. An empirical Bayes model using a competition score for metabolite identification in gas chromatography mass spectrometry. BMC Bioinformatics. 12(1):392.

Kayan A., M.U. Cinar, M.J. Uddin, C. Phatsara, K. Wimmers, S. Ponsuksili, D. Tesfaye, C. Looft, H. Juengst, E. Tholen and K. Schellander. 2011. Polymorphism and expression of the porcine Tenascin $\mathrm{C}$ gene associated with meat and carcass quality. Meat Sci. 89(1):76-83.

Lemos, M.V.A., H.L.J Chiaia, M.P. Berton, F.L.B. Feitosa, C. Aboujaoud, G.M.F. Camargo, A.S.C. Pereira, L.G. Albuquerque, A.M. Ferrinho, L.F. Mueller, M.R. Mazalli, J.J.M. Furlan, R. Carvalheiro, D. M. Gordo, R. Tonussi, R. Espigolan, R.M.O. Silva, H.N. Oliveira, S. Duckett, I. Aguilar and F. Baldi. 2016. Genome-wide association between single nucleotide polymorphisms with beef fattyacid profile in Nellore cattle using the single step procedure. BMC Genomics. 17:213

Lu, P., D. Li and J.Yin. 2008. Flavour differences of cooked longissimus muscle from Chinese indigenous pig breeds and hybrid pig breed (Duroc $\times$ Landrace $\times$ Large White). Food Chem. 107(4):1529-1537.

Maekawa M., Y. Iwayama and T. Ohnishi. 2015. Investigation of the fatty acid transporter encoding genes SLC27A3 and SLC27A4 in autism. Sci. Rep. 5:16239.

Maharani, D., D.W. Seo, N.R. Choi, S. Jin, M. Cahyadi, C. Jo and J.H. Lee. 2013. Association of FASN and SCD genes with fatty acid composition in broilers. CNU J. Agr. Sci. 40(3):215-220.

Nafikov, R.A., J.P. Schoonmaker, K.T. Korn, K. Noack, D.J. Garrick, K.J. Koehler, J. Minick-Bormann, J.M. Reecy, D.E. Spurlock and D.C. Beitz. 2013. Association of polymorphisms in solute carrier family 27, isoform A6 (SLC27A6) and fatty acid binding protein-3 and fatty acid binding protein-4 (FABP3 and FABP4) with fatty acid composition of bovine milk. J. Dairy Sci. 96(9) :1-15

Pensel, N.1998. The future of red meat in human diets. Nutr. Abstr. Rev. (Series A). 68:1-4.

Rioux, V and P. Legrand. 2007. Saturated fatty 
acids: simple molecular structures with complex cellular functions. Curr. Opin. Clin. Nutr. Metab. Care. 10(6):752-758.

Robach, P., G. Cairo, C. Gelfi, F. Bernuzzi, H. Pilegaard, A. Vigano, P. Santambrogio, P. Cerretelli, J.A. Calbet, S. Moutereau and C. Lundby. 2007. Strong iron demand during hypoxia-induced erythropoiesis is associated with down-regulation of ironrelated proteins and myoglobin in human skeletal muscle. Blood. 109(11): 4724-4731.

Rozen, S and H. Skaletsky. 2000. Primer3 on the WWW for general users and for biologist programmers. Methods Mol. Biol. 132:36586.

Silver, N., S. Best, J. Jiang and S.L. Thein. 2006. Selection of housekeeping genes for gene expression studies in human reticulocytes using real-time PCR. BMC Mol. Biol. 7:33.

Simopoulos, A.P. 2008. The importance of the omega-6/omega-3 fatty acid ratio in cardiovascular disease and other chronic diseases. Exp. Bio.1 Med. 233:674-688

Smith, S.B., A.A. Chapman, L.D. Lunt, J.J. Harris and J.W. Savell. 2007. Adiposity of calfand yearling-fed Brangus steers raised to constant-age and constant-body weight endpoints. J. Anim. Sci. 85(5):1136-1143.

Tapiero, H., B. G. Nguyen and P. Couvreur. 2002. Polyunsaturated fatty acids (PUFA) and eicosanoids in human health and pathologies. Biomed Pharmacother. 56(5):
215-222.

Van der Steen, H.A.M., G.F.W. Prall and G.S. Plastow. 2005. Application of genomics to the pork industry. J. Anim. Sci. 83(13):E1E8

Wang, Q., H. Li, N. Li, L. Leng, Y. Wang and Z. Tang. 2006. Identification of single nucleotide polymorphism of adipocyte fatty acid-binding protein gene and its association with fatness traits in the chicken. Poultry Sci. 85(3):429-434

Wang, Y., Q. Zhu, X. Zhao, Y.G. Yao and Y.P. Liu. 2010. Association of FATP1 gene polymorphisms with chicken carcass traits in Chinese meat-type quality chicken populations. Mol. Biol. Rep. 37(8):36833690.

Yu, K., G. Shu, F. Yuan, X. Zhu, P. Gao, S. Wang, L. Wang, Q. Xi, S. Zhang, Y. Zhang, Y. Li, T. Wu, L. Yuan and Q. Jiang. 2013. Fatty ccid and transcriptome profiling of longissimus dorsi muscles between pig breeds differing in meat quality. Int. J. Biol. Sci. 9(1): 108-118.

Zhang, M., C.C. Li, F. Li, H. Li, X.J. Liu, J.J. Loor, X.T Kang and G.R. Sun. 2017. Estrogen Promotes Hepatic Synthesis of Long-Chain Polyunsaturated Fatty Acids by Regulating ELOVL5 at Post-Transcriptional Level in Laying Hens. Int. J. Biol. Sci. 18(7): E1405 